\title{
Metropolitan garbage dumps: possible winter migratory raptor monitoring stations in peninsular India
}

\author{
Satish Pande ${ }^{1}$, Amit Pawashe ${ }^{1}$, Niranjan Sant ${ }^{1}$, Anil Mahabal $^{2}$ \& \\ Neelesh Dahanukar ${ }^{3}$ \\ ${ }^{1}$ Ela Foundation, C-9, Bhosale Park, Sahakarnagar-2, Pune, Maharashtra 411009, India \\ 2 Zoological Survey of India, Western Regional Station, Akurdi, Pune, Maharashtra 411044, India \\ ${ }^{3}$ Indian Institute of Science Education and Research, Sai Trinity, Sutarwadi Road, Pashan, Pune, Maharashtra 411021, India \\ Email: ${ }^{3}$ neeleshdahanukar@rediffmail.com,n.dahanukar@iiserpune.ac.in (corresponding author)
}

Date of publication (online): 26 September 2010 Date of publication (print): 26 September 2010 ISSN $0974-7907$ (online) | 0974-7893 (print)

Editor: R.J. Ranjit Daniels

Manuscript details:

Ms \# 02403

Received 17 February 2010

Finally accepted 14 August 2010

Citation: Pande, S., A. Pawashe, N. Sant, A Mahabal \& N. Dahanukar (2010). Metropolitan garbage dumps: possible winter migratory raptor monitoring stations in peninsular India. Journal of Threatened Taxa 2(10): 1214-1218.

Copyright: (C) Satish Pande, Amit Pawashe, Niranjan Sant, Anil Mahabal \& Neelesh Dahanukar 2010. Creative Commons Attribution 3.0 Unported License. JoTT allows unrestricted use of this article in any medium for non-profit purposes, reproduction and distribution by providing adequate credit to the authors and the source of publication.

Author Details: see end of this article.

Author Contribution: SP, AP, NS and AM conducted field study. ND performed statistical analysis. SP, AM and ND wrote the paper.

Acknowledgements: We thank Hemant Ghate for valuable suggestions on an earlier draft of the manuscript. Prashant Deshpande provided laser operated temperature indicator and video camera. ELA Foundation provided digital still camera and supported the study.

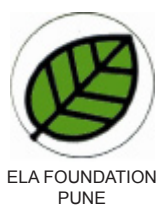

(c) (1) (ே)

OPEN ACCESS | FREE DOWNLOAD
Abstract: Winter raptor migration and movement is poorly documented for peninsular India, mainly due to the lack of geographical bottlenecks. We describe, for the first time, the use of a garbage dump in a metropolitan city as an alternative visual winter raptor monitoring station. The daily count, adult to juvenile ratios and species composition of three migratory raptor species, Steppe Eagle Aquila nipalensis, Black-eared Kite Milvus migrans lineatus and Tawny Eagle Aquila rapax are presented. Ground temperatures at the garbage dump site and surrounding area, and the wing beat rate of migratory raptors before and after arrival in the early morning were measured. A total of 355 raptors migrating over a period of six observation days with 250 adults and 105 juveniles were recorded. The temperature of the garbage dump was significantly higher than the surrounding area, while the wing flapping rate was significantly lower over the garbage dump area. It is possible that migrating raptors use garbage dump thermals in the early morning to save energy with soaring and gliding flight (versus flapping flight). We propose that such sites may be used as visual winter migration monitoring stations in metropolitan cities in peninsular India.

Keywords: Garbage dump, monitoring station, peninsular India, raptors, thermal, winter migration.

Marathi abstract: भारतीय द्वीपकल्पात होणारे शिकारी पक्ष्यांचे हिवाळी स्थलांतर व त्यांचे मार्गक्रमण यांची क्रचित नोंद झालेली आहे. याला कारण म्हणजे स्थलांतराचा अभ्यास करण्या योग्य अशा, भौगोलिक दृष्ट्या जेथे पक्ष्यांची उडताना कोंडी होते, अशा क्षेत्रांचा (बॉटल-नेक) अभाव. योग्य जागांसाठी पर्यायी स्थाने म्हणून आम्ही प्रथमच हिवाळी स्थलांतराचे दृक-निरीक्षण करण्यास उपयुक्त ठरू शकतील अशा महानगरांच्या सभोवतालच्या कचरा डेपोंची उपयुक्तता मांडत आहोत. स्टेप इगल ऑक्रिला निपालेंसिस, ब्लॅक इयर्ड काइट मिल्वस मायग्रन्स लिनिएटस व टॉनी इगल ऑक्रिला रॅपॅक्स यांची दैनंदिन संख्या, प्रौढ व अप्रौढ पक्ष्यांचे प्रमाण व प्रत्येक घटक जातीची मोजणी येथे सादर केली आहे. पहाटेच्या वेळी कचरा डेपोमधील जमिनीचे तापमान व सभोवतालच्या परिसरातील जमिनीचे तापमान, तसेच स्थलांतरित शिकारी पक्ष्यांचे कचरा डेपोवर येण्या आधीचे व आल्यानंतरचे पंख फडकावण्याचे प्रमाण मोजण्यात आले आहे. निरीक्षणांच्या सहा दिवसांत एकुण ३५५ शिकारी पक्ष्यांनी स्थलांतर केले,त्यापैकी २५० प्रौढ होते व १०५ अप्रौढ होते. सभोवतालच्या परिसरापेक्षा कचरा डेपोचे तापमान लक्षणीयरित्या अधिक होते,तसेच पंख फडकावण्याचा वेग कचरा डेपोवर लक्षणीयरित्या कमी होता. स्थलांतर करणारे पक्षी कचरा डेपोवरील गरम हवेच्या झोताचा किंवा बुडबुङ्याचा वापर पहाटे करतात व आपल्या शक्तीची बचत करण्यासाठी या ठिकाणी पंख फडकावण्या पेक्षा भरारणे व तरंगणे अशी युक्ती वापरतात, अशी शक्यता आहे. आम्ही असा प्रस्ताव मांडतो, की अशा जागांचा उपयोग हिवाळीस्थलांतराचे दृक निरीक्षण करण्यासाठी द्वीपकल्पीय भारतातील महानगरांमध्ये केला जाऊ शकतो

\section{INTRODUCTION}

Migration of large raptor populations occurs annually between Eurasia and Africa, North and South America, and Northeast Asia and Southeast Asia and Australia; these migrations are known to occur along specific flyways (Christensen et al. 1981; Shirihai 1987, 1988; Shirihai \& Yekutiel 1991; Shirihai \& Christie 1992; Elphik 1995; Yosef 1995; Meyburg et al. 2003). Central Asian populations of Steppe Eagles are known to winter in Africa (Steyn 1982; Meyburg et al. 2003) and in Nepal (Christensen \& Sorensen 1989; deCandido et al. 2001). Possibly some East Asian populations winter in Tibet (Ellis et al. 2001) and India (Donald 1923; Mikhelson 1982; Fleming 1983; de Roder 1989; Bijlsma 1991; Zalles \& Bildstein 2000; deCandido et al. 2001), but the magnitude and movements of their migration are not known 
(Fergusoon-Lees \& Christie 2001). Visual migration studies are usually conducted at geographical migratory bottlenecks (Safriel 1968; Yosef 1995; Shirihai et al. 2000; Germi et al. 2009). One of the reasons for scanty data on raptor migration and dispersal in peninsular India could be a lack of migratory bottlenecks. There is a need for research to find the whereabouts of Steppe Eagles that migrate across and along the Himalayas in to the Indian subcontinent (deRodger 1989; den Besten 2004).

We have recorded three species of raptors: the Steppe Eagle Aquila nipalensis, Black-eared Kite Milvus migrans lineatus and Tawny Eagle Aquila rapax, migrating in winter from north to south near Pune ( $\left.18^{\circ} 31^{\prime} \mathrm{N} \& 73^{\circ} 51^{\prime} \mathrm{E}\right)$, Maharashra, India.

The Steppe Eagle is a winter visitor to northern India, south up to Belgaum and east to south Orissa (Ali \& Ripley 1968; Grimmett et al. 1998; Kazmierczak \& van Perlo 2000; Pande et al. 2003; Sant 2005; Rasmussen \& Anderton 2005). Steppe Eagle is described as the commonest large eagle in the world (del Hoyo et al. 1994; Simmons 1997) but their numbers have been decreasing since the 1980's (Yosef \& Fornasari 2004). It breeds in the Palearctic from the Altai to Mongolia and southeastern Siberia. The winter migration to India is possibly over the Himalaya (Ali \& Ripley 1968; de Roder 1989; Bijlsma 1991).

The Tawny Eagle is the commonest resident Indian Eagle, but it also occurs in Burma (Ali \& Ripley 1968; Inskipp \& Inskipp 1991). Data on local migration is not available but there is a definite augmentation in their numbers in winter from December and sudden drop after March (unpublished observations of authors for past ten years). We therefore grouped the Tawny Eagles as winter migrants, either local or extralimital.

The Black-eared Kite is a winter migrant to northern and southern peninsular India at least up to $18^{\circ} \mathrm{N}$. It breeds in Ladakh, northern Kashmir, possibly in the Himalaya between 1500 and 4500 m, and in higher hill ranges of Assam, south of Brahmaputra in India; and also in west Siberia east to Transbaikalia; Japan south to Transcaspia; Turkestan and northern China (Ali \& Ripley 1968).

In this paper we describe the migration pattern of three species of raptors, their adult to juvenile ratios and wing beat count at the survey site. We also highlight for the first time the importance of city garbage dumps as possible monitoring stations for the study of the dispersal of winter migrating raptors in peninsular India.

\section{MATERIAL AND METHODS}

Visual surveys of autumn migration were conducted with $10 \times 40$ binoculars and the species were photographically recorded for documentation. Studies were conducted from 0620 to $0940 \mathrm{hr}$ and were supplemented by observations at noon and evening from 25 December 2005 to 10 January 2006 for 120 observation hours. Our survey site was an open plot of arid habitat about $500 \times 500$ m, comprised of undulating grassy slopes of stony country adjoining the garbage dump of Pune metropolis at Devachi Uruli (18 $27^{\prime} 56^{\prime \prime} \mathrm{N} \& 7^{\circ} 57^{\prime} 04^{\prime \prime} \mathrm{E}$, from 520 to $611 \mathrm{~m}$ elevation) over $0.66 \mathrm{~km}^{2}$ area. The time of sunrise and timing and duration of arrival and departure of migrating raptors and dates of migration were noted. The species of raptors, their respective numbers and proportion of adult to juvenile birds were documented. Raptor identification and aging of birds as to adult or juvenile was possible from field guides (Clark \& Yosef 1998; Grimmett et al. 1998; Kazmierczak \& van Perlo 2000; Pande et al. 2003). Ground surface temperatures at three sites, in the garbage dump, the stage post and from 1 to $6 \mathrm{~km}$ surrounding the stage post were recorded with an Optex Thermohunter PT-3LD class 2 laser operated temperature indicator. The activities of raptors were also studied. The direction of arrival and departure were recorded and their methods of arrival and departure flight (flapping or soaring-gliding) were noted along with the wing beat count per minute. Only wing beat counts of raptors that flew without stopping over the garbage dump site were considered for analysis. Some raptors stopped for a short time (up to 30 minutes) at the study area and then departed; their wing beat counts were not included in the analysis.

\section{RESULTS}

The sunrise was around $0713 \mathrm{hr}$ during observation days. The time of arrival of the raptors was at $0640 \mathrm{hr}$ and all the raptors departed by 0940hr. Raptors arrived from the northwest in a flapping flight and departed southwards soaring/gliding and rising on garbage dump

Table 1. Daily migration pattern of raptors in December-January (2005-2006).

\begin{tabular}{|l|c|c|c|c|c|c|c|}
\hline Eagle & $\mathbf{2 8 - x i i - 2 0 0 5}$ & $\mathbf{2 9 - x i i - 2 0 0 5}$ & $\mathbf{0 1 - i - 2 0 0 6}$ & $\mathbf{0 4 - i - 2 0 0 6}$ & $\mathbf{0 5 - i - 2 0 0 6}$ & $\mathbf{0 6 - i - 2 0 0 6}$ & Total \\
\hline Steppe Eagle & 18 & 30 & 25 & 26 & 16 & 19 & 134 \\
\hline Tawny Eagle & 00 & 08 & 13 & 10 & 08 & 25 & 64 \\
\hline Black-eared Kite & 00 & 47 & 18 & 33 & 35 & 24 & 157 \\
\hline Total & 18 & 85 & 56 & 69 & 59 & 68 & 355 \\
\hline
\end{tabular}


Table 2. Adult to juvenile ratios of winter migrating raptors in December-January (2005-2006).

\begin{tabular}{|c|c|c|c|c|}
\hline Age & $\begin{array}{c}\text { Steppe } \\
\text { Eagle }\end{array}$ & $\begin{array}{c}\text { Tawny } \\
\text { Eagle }\end{array}$ & $\begin{array}{c}\text { Black- } \\
\text { eared Kite }\end{array}$ & Total \\
\hline Adult $(\mathrm{A})$ & 93 & 48 & 109 & 250 \\
\hline Juvenile $(\mathrm{J})$ & 41 & 16 & 48 & 105 \\
\hline A $: \mathrm{J}$ & $1: 0.44$ & $1: 0.33$ & $1: 0.44$ & $1: 0.42$ \\
\hline
\end{tabular}

thermals. The daily migration patterns for Steppe Eagle, Tawny Eagle and Black-eared Kite are shown in Table 1. A total of 355 winter migrant raptors were counted during six observation days. A maximum of 29 resident Black Kites Milvus migrans was also recorded throughout the observation days. Adult to juvenile ratios of three species of migratory raptors were recorded (Table 2). Migrants were not noticed prior to 28 December 2005 and migration stopped after 7 January 2006. Reverse summer migration of raptors at the same site was looked for but did not occur during March and April, 2006.

Ground temperatures at three sites, recorded during the duration of migration, were taken between 0640 and $0740 \mathrm{hr}$. The average ground temperature at the garbage dump site was $17.4^{\circ} \mathrm{C}\left(\mathrm{n}=34,14-21^{\circ} \mathrm{C}, \mathrm{SD} 1.38\right)$ taken from mixed garbage heaps of organic and inorganic refuse. The average ground temperature at the stage post site was $13.5^{\circ} \mathrm{C}\left(\mathrm{n}=34,12-15^{\circ} \mathrm{C}\right.$, SD 0.7) taken from basalt rock, hard ground and loamy soil of grassy slopes. The average ground temperature at 1 to $6 \mathrm{~km}$ surrounding the stage post site was $9^{\circ} \mathrm{C}\left(\mathrm{n}=34,5-10^{\circ} \mathrm{C}\right.$, SD 1.0) taken from soil, wet grass, rocky areas and metal artifacts like poles, gates, etc. The difference between ground temperatures of the three sites was significant $\left(F_{2}\right.$, $\left.{ }_{99}=497.46, \mathrm{p}<0.0001\right)$ (Fig. 1).

Prior to arriving at the garbage dump site the wing beat rates per minute were: Steppe Eagles 13.8 (SD 2.1, $\mathrm{n}=49$ ), Tawny Eagles 13.4 (SD 1.5, $\mathrm{n}=28$ ) and Blackeared Kites 15.1 (SD 1.6, $\mathrm{n}=54$ ). After arrival over the garbage dump thermal the wing beat rates per minute were: Steppe Eagles 8.6 (SD 1.4, $n=49$ ), Tawny Eagles 6.8 (SD 0.8, n = 28) and Black-eared Kites 9.1 (SD 1.5, n $=54$ ). For each species the wing beat rate prior to arrival at the garbage dump site and on the site was significantly different and was less on the garbage dump site (Fig. 2). Raptors that halted at the study site departed within 30 minutes after arrival. They did not eat anything during the halt.

\section{DISCUSSION}

Visual migration surveys are often the best and the only available indices of migratory raptor populations that have wide nesting habitats (Yosef \& Fornasari 2004), especially for Steppe Eagle and Black-eared Kite. Nonavailability of geographical bottlenecks usually makes such surveys difficult, as in case of peninsular India. However, inland visual raptor migration surveys were conducted in Indonesia and were shown to be useful (Germi 2005; Germi \& Wahiyo 2006). Therefore identification of stage posts and areas where raptors may converge during migration become important for enabling visual migration surveys. However, different sites and routes may be used for autumn and spring migration (Yom-Tov 1984; Yom-Tov \& Tchernov 1988) and we have recorded that our study site was used by raptors only during winter migration.

The usual criteria for designating a raptor as a migrant

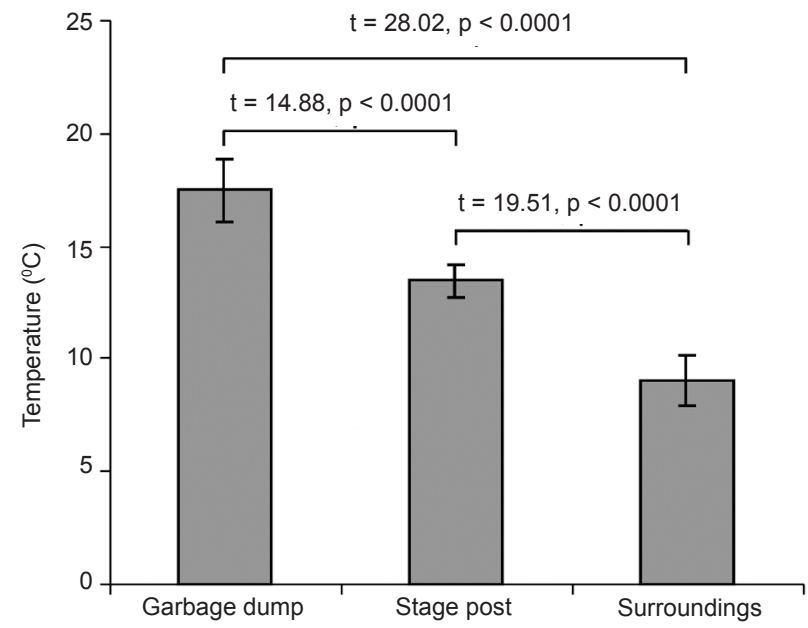

Figure 1. Mean and standard deviation of temperatures at three sites: garbage dump, stage post and surroundings. The temperature difference between three sites is significant $\left(F_{2,99}=497.46, p<0.0001\right)$.

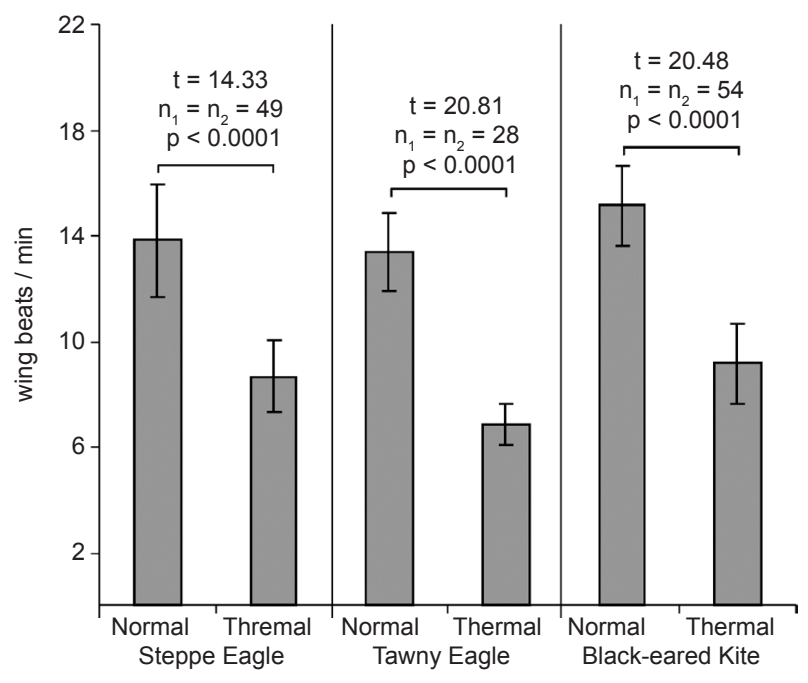

Figure 2. Mean and standard deviation of wing beat rates of three species of migratory raptors before arrival (normal) and over the garbage dump site (thermal). The wing beat rate over the thermal is significantly lower. 
are their known migratory status, as in case of Steppe Eagles and Black-eared Kites or sudden augmentation in populations in winter, as in case of Tawny Eagles. Further, based on our observations we designated a raptor to be in passage and using the garbage dump plot as a stage post and not as the final destination when: (a) raptors arrived from the northwest direction and flew overhead towards south, or (b) they arrived from the northwest direction and stopped at the stage post for a short time before proceeding southwards but they did not eat at the stage post. All of the migrating raptors flew southwards by $0940 \mathrm{hr}$, in contrast to the resident Black Kites that were observed at the site throughout the day.

The adult to juvenile ratios of Steppe Eagle, Blackeared Kite and Tawny Eagle were 1:0.44, 1:0.44 and $1: 0.33$ respectively. Adult to juvenile ratios are useful to evaluate the recruitment rate and as ecological indicators (Yosef 2009). The wintering grounds of the adults and juveniles may be different (Brown et al. 1982; Steyn 1982; Shrihai et al. 2000) or similar (Meyburg et al. 2003), hence such data from one study site should be interpreted with caution.

The effect of weather on migration is well known (Meyburg et al. 2002; den Besten 2004; Elkins 2004; Germi et al. 2009). It is known that thermal soaring migrants find thermals late in the morning and then migrate usually after $0900 \mathrm{hr}$ (deCandido et al. 2001). Early morning migration of Chinese Sparrow-hawks Accipiter soloensis and Greyfaced Buzzard-Eagle Butastur indicus using flapping flight and utilizing head winds is reported (Sun et al. 2003; Tsai et al. 2003; Germi et al. 2009). Further, use of highways as flyways in early morning by raptors by utilizing the heat generated by the tarred roads is reported (Yosef 2009). We observed the migrants prior to sunrise, utilizing garbage dump thermals as an aid to migration. The organic refuse in the garbage dump and basalt rock in the immediate vicinity of the dump, together constituted almost $80 \%$ of the area of the stage post, were responsible for higher temperatures at these two sites. Eagles of all the three species observed by us generally resort to continuous flapping flight, a method that demands high energy. The alternative utilization of garbage dump thermals for ascending and then proceeding south, utilizes soaring, which demands comparatively less energy. We recorded that the wing flapping rates of migrating eagles over the dump site were significantly lower than before arrival at the site. It could be an adaptive energy saving migratory strategy of eagles in early morning (Yosef 2009). We noticed resident Black Kites soaring over the garbage dump thermals early morning every day throughout the year. It is likely that they may have attracted the attention of the migrating raptors to this site.

Our observations are restricted to a large garbage dump near Pune metropolis. Hence, the raptors observed by us represent a fraction of the migration that could be occurring across India. Several metropolitan cities exist in India where potential raptor migration may be visible over respective garbage dumps at appropriate time. We propose that visual autumn migratory raptor monitoring surveys at garbage dumps of various metropolitan cities may be undertaken as an aid to assess early morning winter migration as a tool for estimating their wintering populations in peninsular India. Several such surveys would give us a larger picture of true magnitude of raptor dispersal and migration and their flyways in India.

\section{REFERENCES}

Ali, S. \& S.D. Ripley (1968). Handbook of the Birds of India and Pakistan, together with those of Bangladesh, Nepal, Bhutan and Sri Lanka, Volume 1, Divers and Hawks. Oxford University Press, New Delhi, 380pp.

Bijlsma, R.G. (1991). Migration of raptors and Demoiselle Cranes over central Nepal. Birds of Prey Bulletin 4: 73-80.

Brown, L.H., E.K. Urban \& K.B. Newman (1982). The birds of Africa, Volume I. Academic Press, London, 521pp.

Christensen, S. \& U.G. Sorensen (1989). A review of the migration and wintering of Aquila pomarina and Aquila nipalensis orientalis, pp. 139-150 In: Meyburg, B.U. \& R.D. Chancellor (eds.). Raptors in The Modern World. Proceedings of the 3rd World Congress on Birds of Prey and Owls, Berlin, $612 p p$

Christensen, S., O. Lou, M. Muller \& H. Wohlmuth (1981). The spring migration of raptors in southern Israel and Sinai. Sandgrouse 3: 1-42.

Clark, W.S. \& R. Yosef (1998). In-hand Raptor Identification Guide. IBCE Publication 7, Eilat, 144pp.

de Candido, R., A. Deborah \& K. Bildstein (2001). The migration of Steppe Eagles (Aquila nipalensis) and other raptors in Central Nepal, Autumn, 1999. Journal of Raptor Research 35(1): 35-39.

de Roder, F.E. (1989). The migration of raptors south of Annapurna, Nepal, autumn 1985. Forktail 4: 9-17.

del Hoyo, J., A. Elliott \& J. Sargatal (eds.) (1994). Handbook of the Birds of the World, Volume 2, New World Vultures to Guineafowl. Lynx Edicions, Barcelona, 638pp.

den Besten, J.W. (2004). Migration of Steppe Eagles Aquila nipalensis and other raptors along the Himalayas past Dharamsala, India, in autumn 2001 and spring 2002. Forktail 20: 9-13.

Donald, C.H. (1923). Migration of eagles. Journal of the Bombay Natural History Society 29: 1054-1055.

Elkins, N. (2004). Weather and Bird Behaviour. T \& A D Poyser, London, 280pp.

Ellis, D.H., S.L. Moon \& J.W. Robinson (2001). Annual movements of a Steppe Eagle (Aquila nipalensis) summering in Mongolia and wintering in Tibet. Journal of the Bombay Natural History Society 98: 335-340.

Elphik, J. (1995). Atlas of Bird Migration. Random House, New York, 180pp.

Ferguson-Lees, J. \& D.A. Christie (2001). Raptors of the World. Christopher Helm, London, 992pp.

Fleming, R.L. (1983). An east-west Aquila eagle migration in the Himalayas. Journal of the Bombay Natural History Society 80: 58-62.

Germi, F. (2005). Raptor migration in east Bali, Indonesia: observations from a bottleneck watch site. Forktail 21: 9398.

Germi, F. \& D. Waluyo (2006). Additional information on the autumn migration of raptors in east Bali, Indonesia. Forktail 22: 71-76.

Germi, F., G.S. Young, A. Salim, W. Pangimangen \& M. 
Schellekens (2009). Over-ocean raptor migration in a monsoon regime: spring and autumn 2007 on Sangihe, North Sulawesi, Indonesia. Forktail 25: 104-116.

Grimmett, R., C. Inskipp \& T. Inskipp (1998). Birds on the Indian Subcontinent. Christopher Helm, London, 888pp.

Inskipp, C. \& T. Inskipp (1991). A Guide to The Birds of Nepal, Second Edition. Christopher Helm, London, 400pp.

Kazmierczak, K. \& B. van Perlo (2000). A Field Guide to the Birds of India, Sri Lanka, Pakistan, Nepal, Bhutan, Bangladesh and the Maldives. Om Book Service, New Delhi, 352pp.

Meyburg, B.U., J. Matthes \& C. Meyburg (2002). Satellite-tracked Lesser Spotted Eagle avoids crossing water at the Gulf of Suez. British Birds 95:372-376.

Meyburg, B.U., P. Paillat \& C. Meyburg (2003). Migration routes of Steppe Eagles between Asia and Africa: a study by means of satellite telemetry. The Condor 105(2): 219-227.

Mikhelson, K.A. (1982). Steppe Eagle Aquila nipalensis, pp. 92-95. In: Mikhelson, K.A. \& Y.A. Viksne (eds.), Migrations of Birds of Eastern Europe and Northern Asia. Falconiformes-Gruiformes. "Nauka" Press, Moscow, 286pp.

Pande, S., S. Tambe, C.F. Francis \& N. Sant (2003). Birds of Western Ghats, Konkan and Malabar (Including Birds of Goa). Oxford University Press and Bombay Natural History Society, India, 371pp.

Rasmussen, P.C. \& J.C. Anderton (2005). Birds of South Asia: The Ripley Guide, Volums 1 \& 2. Smithsonian Institution \& Lynx Edicion. Washington D.C. and Barcelona, 1072pp.

Safriel, U. (1968). Bird migration at Eilat, Israel. Ibis 110: 283-320.

Sant, N. (2005). Sighting of Steppe Eagles Aquila nipalensis near Belgaum, Maharashtra, India. Indian Birds 1(4): 96.

Shirihai, H. (1987). Eilat - an intercontinental highway for migrating raptors. International Birdwatching Center, Eilat, Israel, 80pp.

Shirihai, H. (1988). Raptor migration at Eilat in Spring 1987. Torgos 13: 47-53.

Shirihai, H. \& D.A. Christie (1992). Raptor migration at Eilat, Israel. British Birds 85: 141-186.

Shirihai, H. \& D. Yekutiel (1991). Raptor migration at Eilat - spring 1988, pp 2-12. In Yekutiel D. (ed.), Raptors in Israel: Passage and Wintering Populations. International Birdwatching Center, Eilat, Israel, 64pp.

Shirihai, H., R. Yosef, D. Alon, G.M. Kirwan \& R. Spaar (2000). Raptor migration in Israel and the Middle East - a summary of 30 years of field research. International Birding and Research Centre in Eilat, Israel, 191pp.

Simmons, R.E. (1997). Steppe Eagle, pp. 180. In: Harrison, J.A., D.G. Allan, L.G. Underhill, M. Herremans, A.J. Tree, V. Parker \& C.J. Brown (eds.). The Atlas of Southern African Birds Vol. 1: Non-passerines. Birdlife of South Africa, Johannesburg, 900pp.

Steyn, P. (1982). Birds of Prey in Southern Africa. David Philip Publishers, Cape Town, 312pp.

Sun, Y.H., C.Y. Lan, T.W. Deng \& Y.J. Tsai (2003). Use of weather radar in studying the migrating Chinese Sparrow Hawk at Kenting, pp. 34. In: Abstracts and Proceedings $3^{\text {rd }}$ Symposium on Asian Raptors. ARRCN, Kenting, Taiwan, 79pp.

Tsai, Y.J., H.H. Tang \& C.Y. Lin (2003). Research on population and pass time of autumn migratory hawks in Kenting area 1990-2002, pp. 38. In: Abstracts and Proceedings $3^{\text {rd }}$ Symposium on Asian Raptors. ARRCN, Kenting, Taiwan, 79pp.

Yom-Tov, Y. (1984). On the difference between the spring and autumn migrations in Eilat, southern Israel. Ringing and Migration 5:141-144.

Yom-Tov, Y. \& E. Tchernov (1988). Bird migration in Israel, pp. 497-514. In: Yom-Tov, Y. \& E. Tchernov (eds.). The Zoogeography of Israel. W. Junk, Dordrecht, Netherlands, 600 p.

Yosef, R. (1995). Spring 1994 raptor migration at Eilat, Israel. Journal of Raptor Research 29(2): 127-134.

Yosef, R. (2009). Highways as flyways: Time and energy optimization in migratory Levant Sparrowhawk. Journal of Arid Environments 73: 139-141.

Yosef, R. \& L. Fornasari (2004). Simultaneous decline in Steppe Eagle (Aquila nipalensis) populations and Levant Sparrowhawk (Accipiter brevipes) reproductive success: coincidence or a Chernobyl legacy? Ostrich 75(1\&2): 20-24.

Zalles, J.I. \& K.L. Bildstein (eds.) (2000). Raptor watch: a global directory of raptor migration sites. Birdlife International and Hawk Mountain Sanctuary, Cambridge, 419pp.
Author Details: SATISH PANDE is a Fellow of Maharashtra Academy of Sciences. He is an Interventional VascularRadiologistandAssociate Professor of Radiology at B.J. Medical College, Pune. He works in ecology and field ornithology and has made several video films on raptor ecology, marine ecosystem and conservation. He has published more than 40 papers and has authored several field guides and popular books on ornithology, nature education, orchids and other subjects for popularization of science and to promote conservation.

Амiт PAWASHE is an avid conservationist with interest in field work related to ornithology. $\mathrm{He}$ likes to draw birds. He gives lectures and conducts seminars to promote nature conservation.

NiRANJan Sant is a mechanical engineer. He likes field work related to ornithology. He has coauthored several ornithological field guides. He is a nature photographer and has won several awards for bird photography.

ANIL MAHABAL has retired as the Additional Director of the Zoological Survey of India, Akurdi, Pune. He has published several papers on ornithology and ecology and has authored books related to nature. He works for popularization of science and for promoting conservation.

NeElesh Dahanukar works in ecology and evolutionary biology with an emphasis on theoretical and statistical analysis. 